\title{
Beckett, Sade, The Avengers: Patrick Magee and character acting in the 1960s
}

Article

Accepted Version

Carville, C. (2022) Beckett, Sade, The Avengers: Patrick Magee and character acting in the 1960s. Studies in Theatre and Performance, 42 (2). pp. 182-195. ISSN 2040-0616 doi: https://doi.org/10.1080/14682761.2020.1757318 Available at https://centaur.reading.ac.uk/83183/

It is advisable to refer to the publisher's version if you intend to cite from the work. See Guidance on citing.

To link to this article DOI: http://dx.doi.org/10.1080/14682761.2020.1757318

Publisher: Routledge

All outputs in CentAUR are protected by Intellectual Property Rights law, including copyright law. Copyright and IPR is retained by the creators or other copyright holders. Terms and conditions for use of this material are defined in the End User Agreement.

\section{www.reading.ac.uk/centaur}

\section{CentAUR}

Central Archive at the University of Reading

Reading's research outputs online 


\section{Beckett, Sade, The Avengers: Patrick Magee and Character Acting in the 1960s.}

Patrick Magee was Samuel Beckett's close collaborator and friend who, through his monologues on BBC radio in the early 1960s, shaped the parameters of a generic Beckettian character, one that can still be detected in the production, reception and understanding of Beckett's work today. ${ }^{1}$ It has been estimated that these classic early broadcasts, taking place over a relatively short period, reached audiences far in excess of any of the other avenues available to Beckett at the time. ${ }^{2}$ Yet it has not been sufficiently understood that Magee's performances emerge from a wide and shifting field of biographical, aesthetic, professional and economic forces, given his centrality not only to Beckett's reception, but to many other areas of performance, from classic West End theatre to horror film, countercultural provocation to iconic Sixties television series.

Magee's distinctive realization of Beckett's anonymous, isolated, seemingly ancient voices in his broadcasts of challenging work like From an Abandoned Work, Molloy, Malone Dies and The Unnamable took place in a context of his sustained experiment with the nature and function of character across several media, and in what follows I want to think through the nature and consequences of this mobility. Although Performance Studies has rightly carefully discriminated between the medium-specific demands of acting in theatre, film and television, it is the remarkable consistency of aspects of Magee's style that I

\footnotetext{
${ }^{1}$ For an acerbic aside on Jack McGowran's role in constructing the Beckettian, and Peter Brook's exploitation of it in his 1967 Lear, see Stephen Watts, 'On Retrofitting: Samuel Beckett, Tourist Attraction' in Jaffe A. and Goldman J.,(eds.), Modernist Star Maps: Celebrity, Modernity, Culture (Ashgate, 2010), pp. 207-220. As we shall see Magee's role is a much more powerful and interesting one.

2 Addyman et al, emphasize the importance of the Third Programme for Beckett's reception, estimating 50,000 listeners for his 1958 play All That Fall, while a capacity crowd at the Royal Court Theatre, London was 380 people. See Addyman, Feldman and Tonning, Beckett and Radio: A Reassessment (London: Palgrave,), pp. 6-7.
} 
want to consider. ${ }^{3}$ To do so I will focus on his career from 1958 to 1964, that is to say, from the small part he played in the first airing of Beckett's play All that Fall on the BBC Third Programme, to the Royal Shakespeare Company summer season at the Aldwych in London, which featured Magee as leading man in all four plays staged, including Beckett's Endgame and Peter Weiss's Marat/Sade.

In an immensely suggestive Sight and Sound essay from 1973, the critic Lawrence Shaffer creates a taxonomy of post-war screen performance, making a distinction between 'personality acting' and 'character acting' ${ }^{4}$ In the former the actor seems to simply 'behave', rather than act, with no intrusion of technique. Shaffer's main example is Gene Hackman in Friedkin's 1971 The French Connection. Schaffer's attitude to personality acting is rather ambivalent (he appears to have the Method in his sights). Although he seems to admire certain examples, he reserves his greatest praise for a specific mode of what he refers to as 'character acting'. This is not the character actor as commonly understood, however, the performer who specialises in a generic, fairly limited role (here his example is Donald Pleasance). Rather it is the case of the actor who, while retaining a consistent individual personality, convinces the viewer of the concrete reality of a disparate range of characters (Ralph Richardson is Schaffer's reference now). Such an actor somehow portrays in every role a convincingly inward particularity, while also preserving the distant universality of the star. ${ }^{5}$

Towards the end of his essay Shaffer devotes considerable time to Magee's performance in two of his most celebrated films: Stanley Kubrick's A Clockwork Orange (1972) and Peter Brook's Marat/Sade (1967). Although it is not made entirely clear, Magee seems to be a problem case, falling somewhere between

\footnotetext{
${ }^{3}$ See for recent work on media-specific performance Philip Drake, 'Reconceptualizing Screen Performance', Journal of Film and Video, April 2006, 58/1-2. pp. 84-94; 'Reframing Television Performance', Journal of Film and Video, October 2016, 68/ 3-4, pp. 6-17.

4 'Some Notes on Film Acting', Shaffer, L. Sight and Sound; Spring 1973; 42, 2; pg. 103-106.

${ }^{5}$ In this it is very similar indeed to Naremore's influential notion of the performance style of the Hollywood star. See Naremore, J., Acting in the Cinema (Berkeley: U of California P, 1988).
} 
three modes: personality acting; the character acting of Richardson et al that Schaffer admires; and the more generic performances of someone like Pleasance. Thus in A Clockwork Orange, according to Schaffer, Magee supplies 'the rolling eyes and frothy mouth of Tales from the Crypt.' The latter was an Amicus portmanteau film directed by Freddie Francis in 1972, where Magee played the leader of a bloody rebellion in a care home for the blind. It is just one of the many British horror and exploitation films that he acted in from 1961 onwards. ${ }^{6}$ Shaffer thinks Kubrick demanded overt 'expression' and Magee dutifully turned in a generic, excessive, non-naturalistic performance. And so this is an example of an actor allowing generic idioms to dominate a role. In Schaffer's terms: 'the problem with Magee is that certain conventions of horror-film acting allowances for manipulative signalling normally permitted him - become embarrassing her .... Because (like Pleasance) he has enormous technical resources - lots of strings to pull and a lot of ways of pulling them - he achieves a weird mixture of the funny and the horrible. But he is never emotionally moving'. ${ }^{7}$ By contrast Schaffer describes Malcom McDowell's performance in the same film as 'the carefree expressiveness of personality acting when it has found a home for itself in an archetypal role'. Schaffer then goes on almost immediately to lavishly praise Magee's depiction of Sade in Peter Brook's film of Marat/Sade as an example of the kind of character acting he admires. We will return to Shaffer's fascinating and conflicted description of this performance at the end of this essay.

'Notes on Film Acting' is important for my argument here in that it attributes Magee's supposed failure in Clockwork Orange to his regular experience in popular and cult film. The conventions of the latter, it appears, have contaminated his style, resulting in a tendency to foreground what Schaffer calls the 'apparatus'

\footnotetext{
${ }^{6}$ For the British horror boom see Hutchings, P., Hammer and Beyond: The British Horror Film. (Manchester: Manchester University Press, 1993).

${ }^{7}$ Again, this seems to be what Naremore calls 'ostensive' film acting. See Naremore, p. 17.
} 
of his acting. Yet this relationship between the 'apparatus' of acting, genre and media form is suggestive in attempting to link up disparate facets of Magee's career, and to reflect on how he drew on various performance styles. More precisely, Schaffer's typology of character acting opens the possibility of a genealogy of Magee's style across several media: radio, television, film and theatre. ${ }^{8}$ In order to do this, however, we first have to go back to the beginning.

After a period with Anew McMasters' travelling theatre in Ireland, and work with the Group and Arts Theatres in Belfast, Magee moved to London in $1955 .{ }^{9}$ This experience of migration is something he shared with many others of his generation: Magee left Ireland because he was looking for employment, and the experience marked him. ${ }^{10}$ In the late 50s and early 60s he became part of an Irish theatre in exile that would have a major contribution to make to the cultural history of both nations. Dudley Sutton, who acted with Magee in this period, provides a vivid picture of the style of acting the Irish brought to London:

It was fantastic. I loved it. There was a sort of glory about it. I loved Irish actors who came to London at that time. They'd come to work as if they were a plumber on the job ... I like the ease with which they dealt with the theatre. It was much more physical in a friendly way. ${ }^{11}$

Like many actors, Irish and others, Magee gravitated to West London. Here in the down-at-heel but cosmopolitan areas of Hammersmith and Notting Hill, several tiny new theatre-clubs had opened. Magee quickly joined ex-members of MacMaster's troupe like Grainne O’Shannon, exiles from the Belfast Group J.G.

\footnotetext{
${ }^{8}$ For a careful analysis of post-War transmedia performance see Palmer, L. (2015). 'And Introducing Elvis Presley': Industrial convergence and transmedia stardom in the rock 'n' roll movie. Music, Sound and the Moving Image, 9(2), 177-190.

${ }^{9}$ See Magee P., Letter to Gordon Smith, Drama Booking Manager, $14^{\text {th }}$ April 1955, BBC Written Archives, RCONT1: Radio Contributors, Patrick Magee, Artist File 1 (1955-1962).

${ }^{10}$ See Edna O'Brien's account of a lunch with Magee in The Country Girls: A Memoir (London: Faber, 2013), when he declared himself fated from birth 'for the boat'.

${ }^{11}$ Adam Smith, 'Dudley Sutton - Interview Transcript' (2010), British Library, Theatre Archive Project, https://sounds.bl.uk/Arts-literature-and-performance/Theatre-Archive-Project/024M-C1142X000284-0100V0
} 
Devlin, Allan McClelland and Harry Towb, Abbey-trained actors like Jackie MacGowran, and other jobbing Irish such as Sheila Ward, Jack Cunningham and Desmond Jordan, to set up The Irish Players, putting on O'Casey plays in a theatre-club in Notting Hill, and then, after created a stir with their performances, at the much bigger Lyric in Hammersmith. ${ }^{12}$ The reception of the acting in these plays suggests a heightened style that departs from the British norm, but also relies on certain conventions. Thus The Stage remarked excitedly that 'a good Irish play will usually seem better than a good English one, for the characters are more naturally self-expressive ... certainly this group play as a remarkable team. West End companies ought to go and look at these players, to see how realism and poetry, comedy and tragedy, can blend in perfectly finished and spontaneous portrayals. ${ }^{13}$ The Times review of Shadow limited itself to remarking on the 'farcical' acting at the Lyric, but the Financial Times said that while Magee was 'amusing', MacGowran was 'an authentic Irish bog sprite conjured straight from a cloud of woodbine smoke'. ${ }^{14}$ It seems that the Players were not above hamming up the stage-Irishry then.

On arrival in London Magee also started looking for work with the BBC, landing several small television and radio roles. ${ }^{15}$ More importantly, he struck up a relationship with the key producers in Portland Place, including Reggie Smith, with whom he became close friends. ${ }^{16}$ Smith in turn introduced him to the circle of Irish writers he worked with, such as Louis MacNeice and W. R Rogers, as well as old BBC acting hands like Harry Hutchinson and Mary O'Farrell. Magee

\footnotetext{
${ }^{12}$ See The Irish Press, 19th Sept. and 24th Oct. 1956.

13 A. M., The Stage, January 17, 1957.

${ }^{14}$ The Financial Times, $17^{\text {th }}$ Jan. 1957.

${ }^{15}$ BBC Written Archives, RCONT1, Magee, Patrick, Radio Contributors, Artist File 1 (1955-1962); TVPF1, Magee Patrick, Television Performers, Artist File 1 (1955-1962).

${ }^{16}$ See Smith's 12th Sept. 1957 reply to Magee's enquiry after work: 'I have very little on hand and there can't be anything immediately, so let's have a drink'. BBC Written Archives, RCONT1, Magee Patrick, Radio Contributors, Artist File 1 (1955-1962).
} 
felt at home in the bohemian haunts of Fitzrovia in the later 50s, and soon became a fixture on the BBC's Third Programme.

There was something of an O'Casey revival in the UK in these years, coinciding with the influx of Irish actors. O'Casey himself was living in Torquay, and in London George Devine was keen to include the Irish dramatist in his 'Writer's Theatre' at the Royal Court, casting Magee in his 1959 Cock a Doodle Dandy at O'Casey's insistence. ${ }^{17}$ At the BBC The Plough and the Stars was broadcast on $27^{\text {th }}$ January 1957 (shortly after All that Fall) and featured the Irish Players Jack McGowran, Harry Hutchinson, Shelagh Ward, Peggy Marshall, J.G. Devlin and Donal Donnelly. Magee went on to act in Juno and the Peacock for his fellow Ulsterman and newly-appointed BBC producer John Gibson in February, and featured in Red Roses for Me in April, also directed by Gibson. Shadow of a Gunman was transmitted on ITV Playhouse in July, while there had been a BBC TV Juno broadcast on St. Patrick's Day.

The Irish Players was a short-lived company, splitting up shortly after McGowran, its main moving force, was unexpectedly contracted to spend six weeks shooting in Spain in early $1957 .{ }^{18}$ In the subsequent months and years, many of the actors involved, Magee especially, relied on the BBC as a relatively steady and reliable source of income. The O'Casey plays at the Lyric and the BBC thus catalysed an ensemble of Irish actors, and an ensemble style of character acting - comic, declamatory, idiomatic, self-consciously exoticising that British radio would draw on in its expansion of Irish drama throughout the late 1950s and early 1960s. We should remember this, and the fact that the Players were immersed in O'Casey throughout the late 1950s, when considering the performance style of All that Fall. For Beckett's play, with its cast of ten (his biggest by far), showcases the strengths of the type of playing that had been

\footnotetext{
${ }^{17}$ Murray, C., Sean O'Casey: A Biography (Gill \& Macmillan, 2004), p. 414.

${ }^{18}$ See The Irish Press, October 241956.
} 
evolving amongst local Irish actors. Indeed there is in Beckett's play a reliance on ensemble technique and related tropes of community, idiom and Irishness that will become familiar on the Third. The characters are overtly stock, interchangeable, defined through their relationship with each other rather than psychological depth. In this way All that Fall seems designed to both showcase, and elaborately deform, a particular mode of performance that was already in place when Beckett was asked to write the play.

Ernest Mathijs has suggested that recent ensemble playing on screen, when a gang of relatively unknown actors functions as a group across a series of movies, employs an alternative method to the star system. In the absence of big individual names, audience attention ranges widely across the cast, and so the acting signifies differentially, through contrast, allusion and relay to produce what he calls 'referential acting' ${ }^{19}$ Mathijs also argues that this kind of performance in contemporary popular comic cinema is tolerant of strategies that in other contexts we might call Modernist, or even Postmodernist. ${ }^{20}$ Lack of psychological depth, and non-naturalistic typification of individuals through repetitious character traits in widely varying settings, serve to challenge mainstream cinema's default realism.

This model of referential acting is germane to the relationship between The Irish Players and their repertoire, the performances in All that Fall, and Magee's subsequent career. As we have seen, ensemble acting is key to O'Casey's Trilogy, especially if it is played for laughs, as it seems to have been by the Players. The implications of Mathijs argument is that ensemble playing depends on, or is conducive to, a certain kind of character acting, where meaning is strongly differential rather than conventionally expressive. That is to say, the actors rely

\footnotetext{
${ }^{19}$ Ernest Mathijas 'Referential Acting and the Ensemble Cast', Screen, 2011, Volume 52, Issue 1, pp. 89-96.

${ }^{20}$ Ibid., pp. 91-92.
} 
on strong contrasts between types: in O'Casey, for example, these would be the drunk, the zealot, the tart-with-a-heart, the long-suffering mother. All that Fall too lends itself, indeed exploits with gusto, this style. ${ }^{21}$ What is more, the use of the Players as cast, at the same time as they are rehearsing and acting in O'Casey, undoubtedly and inevitably intensified these resonances between the two Irish writers.

In sum the group of migrant actors associated with the Irish Players quickly established themselves as a highly coherent and efficient bloc, skilled in creating an immediately recognisable vocal sound-world for radio broadcasts, and exhibiting a distinctive ensemble style in doing so. After the success of All that Fall it is not surprising that a series of O'Casey plays were broadcast on both radio and $\mathrm{TV}$, or that subsequently Irish drama attained a presence on the Third that it never had before. ${ }^{22}$ This is the context in which the Magee Beckett broadcasts, foundational for the Anglophone reception of Beckett, must be considered.

The first Beckett monologue Magee worked on was From an Abandoned Work. Barbara Bray recalled that this was a piece that Beckett 'had enormous trouble with', as many of the actors that the producer Donald MacWhinnie auditioned wanted to use 'their full diapason when acting', while what Beckett was looking for was an 'almost lifeless croak'. ${ }^{23}$ Bray's comments are enlightening, as they suggest how Magee's soon-to-be-trademark vocal style was suggested in part, through MacWhinnie, by Beckett himself. Magee, it is safe to say, as a protégé

\footnotetext{
${ }^{21}$ Hence Eric Tonning's description of the play as 'a mad old hag of an Irishwoman and an entourage of eccentric villagers gushing blarney’. Addyman et al, p. 69.

22 See Bloom, E. C., The Wireless Past: Anglo-Irish Writers and the BBC, 1931-1968 (Oxford: Oxford University Press), p. 136. Bloom argues that previously the Third Programme had aspired to separate itself from Irish idioms. ${ }^{23}$ Kẹdzierski, M.`'Barbara Bray: In Her Own Words', Modernism/modernity, Volume 18, Number 4, November
2011, pp. 887-897, p. 891.
} 
of the classic actor-director MacMaster, loved to use the full range of his voice, just like any other actor. Indeed reviews of his performances from the mid-1940s onwards make no mention of any distinctive vocal traits, while after 1957 comments on the droning, or monotonous nature of his voice, are ubiquitous. From an Abandoned Work is a major turning point then, when Magee adds, under the influence of MacWhinnie and Beckett, avant-garde performance techniques of oral performance to the ensemble style of character acting he had been evolving with the Players.

In From an Abandoned Work Magee and MacWhinnie retain the Player's whimsical Irish inflections to a degree sufficient to connect to the generic, character-based, sound-world of the voices in All that Fall and O'Casey. Yet Magee also adapts his tone, emphasizing a ticking, guttural note that had been only vestigially present before, so that the performance moves along the spectrum from affectionate caricature to something more recalcitrant and uncanny. The mechanical crackle in the voice is so consistent that one worries for Magee's vocal chords, and at times he allows it to take over completely, so that the sense of the speech is almost lost, and we seem to be listening to a Geiger counter or the ratcheting mechanism of some rickety machine. Occasionally Magee finishes a sentence, yet continues the ticking sound, letting it fade into the aether before beginning the next sentence. It is as if he is allowing himself to be possessed by the medium itself, imitating bursts of static, or the effects of a swaying aerial.

Magee's performance adds enormously to the aesthetic impact of From an Abandoned Work. Without the idiosyncracy of his voicing, we would be left with a meandering vignette, by turns melancholy and lyrical, a character study of no particular experimental value. With it, character is denaturalized in two contrasting ways, as the actor's voice intermittently descends into serrated mechanization, or fattens into a gross guttural materiality, one that might stem from the physicality of the Irish acting style noted by Sutton. If Magee's 
experiences on All that Fall had introduced him to innovative treatment of character by default, as a result of the Irish Players ensemble techniques, in his first monologue he delivers a masterclass in avant-garde defamiliarization, one that sets the tone for his subsequent work with Beckett.

The first broadcast monologue, from Molloy, went out on $10^{\text {th }}$ December 1957, repeated on $13^{\text {th }}$, followed the next evening by From an Abandoned Work, which was repeated on the $19^{\text {th }}$ Malone Dies aired on the $18^{\text {th }}$ and $19^{\text {th }}$ June, and on the $15^{\text {th }}$ October 1958, The Unnamable on $19^{\text {th }}$ January and $10^{\text {th }}$ February 1959. Magee's performances stretched the descriptive capabilities of reviewers considerably, but the responses were electric: for The Listener Magee's voice is 'a prickly growl that was sometimes only just audible'; and again a 'grating, quivering, sexless voice, dry as a cicada's song' ${ }^{24}$

In between the repeat of Malone Dies and the broadcast of The Unnamable, Magee was appearing in Krapp's Last Tape at the Royal Court. The same conjunction of 'the human and the inhuman', the material and the machinic, that Barbara Bray finds in the radio work is at the heart of Krapp's Last Tape, though now it takes place across the split between the recorded, mediated voice that Krapp listens to, and the physical presence of his face. ${ }^{25}$ When Becket says of Magee's performance in the Royal Court that it was his 'best experience in the theatre ever', it must have been this complex development of which he was speaking. ${ }^{26}$ A great deal of the play consists of unalloyed facial expression. Magee's face is a material presence that perdures alongside the younger Krapp's memories and the extraordinarily effective sensual images the recorded voice describes. The play turns on the possibility of the mental picturing of another's thoughts. What does Krapp see, listening to these tapes? What does Krapp feel as

\footnotetext{
${ }^{24}$ Walker, R., The Listener, 19 December 1957; Grandsen, K.W., The Listener, 26 June 1958.

25 Kędzierski M., (2011), Ibid.

${ }^{26}$ Beckett, S., The Letters of Samuel Beckett, Vol. II, Overbeck, L, (ed.) (Cambridge, 2014), p. 179.
} 
he immerses himself in this strange ritual? The audience listens to the tapes alongside the actor, generating their own mental images and affects, but these must also be pitched against the intensely still, embodied face as Magee too strains to hear. Conversely, the affective colouring of our imagination of the remembered scenes will be inflected by Krapp's own subtle, silent, expressive responses. That the enigmatic presence of the onstage image resists the imagination, while also provoking it, is thus essential to the play's dynamic.

In such circumstances, Beckett could not have been looking for a character actor in the popular sense. What the part needed was a quality of withdrawal, reservation and abstraction. The requisite actor must be able to become both a screen onto which the audience projects, and an obstacle to their empathy. It is precisely this tension that one can discern in Ida Kar's magnificent photographs of the rehearsals at the Royal Court. And it is here that another important element in Magee's style emerges, one that is both antithetical and analogous to the subtle, heightened manipulations of his radio voice. The strict separation of voice and face in Krapp allowed Magee to experiment with the monocular, liquid, absent stare, the eyebrows that quiver and knit, the grim, set, yet sensual mouth that allow him to signify fleeting intensities of inwardness like no other actor of his time. This newly restrained style would stand him in good stead later in Beckett, as well as in less significant roles on TV and in film, but it was in the experimental ambience of the Krapp rehearsals that he first perfected it.

By the end of the 1950s Magee had begun to extend his vocal stylings beyond Beckett to other solo radio performances. Of a reading of Synge's poetry, broadcast on $2^{\text {nd }}$ April 1959, David Paul wrote that the sound was 'like a queen wasp waking up spider-webbed inside a skull'. ${ }^{27}$ Six months later, Ian Roger reported that as Antaeus in James Hanley's Gobbet, Magee's 'cracked voice was

\footnotetext{
${ }^{27}$ Paul, D., The Listener, $2^{\text {nd }}$ April, 1959.
} 
suggestive of the deformed body without being as incomprehensible as it has sometimes been in plays [sic] by Mr Beckett'. ${ }^{28}$ Magee then carried the voice into the theatre, with less happy results. A Royal Court production of Ibsen's Rosmersholme in November 1959, where Magee played Ulric Brendel, provoked one reviewer to comment that 'the effect [was] more of caricature than normal characterisation'. ${ }^{29}$ The Irish Times' 'London Letter' concurred: 'Mr Magee's speech seems to have taken on for good the weird sounds that were so effective in his performances of Samuel Beckett'. ${ }^{30}$ Back on radio, critics still seemed content with this development, however. Assessing his headline role in Louis MacNeice's They Met on Good Friday, broadcast $8^{\text {th }}$ December 1959 on the Third, the TLS commented on the way MacNeice used 'modern' documentary effects in recounting the ancient story, and went on: 'Mr Patrick Magee's doomed querulous King Brian is in himself a modernizing factor: Mr Magee's voice turned the most deliberate statements into enigmatic insoluble questions'. This enigmatic quality will become the key transferrable element, of both voice and facial expression, in the actor's work across theatre, film and television.

Shaeffer's typologies of character acting are useful in trying to work out what exactly is going on here. That Magee would use a particular style and voice in the Beckett broadcasts he did is understandable, as he had been coaxed by MacWhinnie and Beckett into developing it. That he would also use the same, idiosyncratic style in broadcasts by other writers is slightly less predictable, though one can account for it in the climate of the rapidly expanding culture industry of the early Sixties. Magee is forging a trademark style that associates his voice, and the radio work he does, with Beckett's considerable, and growing, artistic capital. To extend this into the theatre, and to Ibsen in particular is rather odd, however, and was clearly seen as such by observers. It is here that

\footnotetext{
${ }^{28}$ Roger, I., The Listener, 15th October 1959.

${ }^{29}$ R.B.M., The Stage, 26 November, 1959.

30 'London Letter', The Irish Times, 21 November 1959.
} 
technological and commercial developments seem to overwhelm the actor's ability to control and thematise them in his work. In Shaeffer's terms, Magee appears to be attempting character acting of the second type (that of Ralph Richardson), where an actor is able to mould a distinctive yet flexible 'apparatus' to a range of characters. Yet what transpires is something closer to character acting of the third, and most familiar type to us today, a kind of shorthand where an actor becomes identified with a specific kind of character. The latter modality is more often associated with genre film than either classic cinema or art film. But the distinctive, and fascinating, feature of Magee's case is that the charactertype here is not the generic social or emotional type that actors like Donald Pleasance specialized in, but rather the highly experimental Beckettian persona that he had played such a central role in realising.

While he was playing in Krapp, Magee could also be seen in the cinema as Flynn in Lance Comfort's Rag Doll (1958). In October the same year he appeared on television in Michael Cahill's Gracie. In Alun Owen's The Ruffians, transmitted on BBC TV on $9^{\text {th }}$ October 1960, a critic commented that Magee 'of the strange monotonous voice was excellently cast'.${ }^{31}$ Clearly, in the latter case, Magee is again transferring, with suitable modification, something of the vocal techniques developed through the Beckett radio work to other media. But it was Joseph Losey's The Criminal, shot and released in 1960, that brought him to wider attention for the particular kind of role in which he would specialise onscreen as a character actor. ${ }^{32}$ As Film Monthly put, using an adjective we have already encountered in the radio reviews, he played the 'key figure of the vicious, enigmatically conniving warder'.$^{33}$ This is the first of the pop cultural 'heavies',

\footnotetext{
${ }^{31}$ Crozier, M., The Guardian, 10th Oct. 1960, p. 7.

${ }^{32}$ ? In a contemporary interview Losey said Magee had 'a really creative contribution to make'. See Houston, P. and Gillet J., 'Conversations with Nicolas Ray and Joseph Losey', Sight and Sound, Fall 1961, 30, 4.

33 'The Criminal', Monthly Film Bulletin, January 1960.
} 
as he called them, that Magee will play throughout his career in innumerable bit parts and character acting roles.

These and other reviews limn the way in which Magee's acting style is developing. A review of The Criminal in Sight and Sound also singles out Magee's performance for its specific combination of violence and resistance to interpretation, and significantly makes reference to a key avant-garde literary figure of the 1950s and 1960s: 'its most remarkable characterisation is that of the prison warder, played with controlled viciousness by Patrick Magee. As in a Genet novel, the demarcation between prisoner and warder is ambiguous. ${ }^{34}$

Ambiguous demarcation is the core of Magee's most successful work and it is here that the threads of his post-War career begin to tightly knot themselves. To summarise: between 1957 and 1960, under the pressure of his work for Beckett on radio and for the stage, Magee rapidly develops a personal style based on a distinctive droning monotone and a subtle, restrained visual intensity, which he was then able to transfer to the big and small screens. In doing so he brought a mode of acting bearing traces of avant-garde performance into a much more mainstream arena. At its most successful, this style bears a resemblance to Schaffer's approved mode of character acting, when the actor is able to deploy a powerful, singular, yet ambiguous presence to realise a variety of disparate roles.

Yet the fact that Magee was now increasingly operating in a mass cultural sphere, where subtleties of expression and art are outweighed by practical and commercial concerns, also exerts stylistic pressure. This issues in the more familiar style of character acting, to which many of Magee's smaller TV roles inevitably conformed, with the actor functioning as a generic sign to abet narrative, rather than an articulation of presence, truth or indeed anything at all. A good example is 'The Gilded Cage' the classic episode of The Avengers that

\footnotetext{
${ }^{34}$ Roud, R., Sight and Sound, Fall, 1960, 29, 4.
} 
Magee shot in October 1963, where he plays the wheelchair-bound master criminal J. P. Spagge. The tension and complicity between these two forms of character acting, which is also that between high and popular cultural forms, accounts both for the memorable performances Magee was able to produce in some cases, and the jarring, idiosyncratic and downright ridiculous turns he affected in others.

Two further examples from film demonstrate the way Magee refined his technique in the popular-cultural realm in the early-to-mid-Sixties. The reinedin monotonous voice can be heard to great effect in Roger Corman's Masque of the Red Death (1964). From 1962 Magee had made a series of movies with this notorious producer and director. Shooting all over Europe, such films - The Young Racers (1963), Dementia 13 (1963) and Portrait in Terror (1963) - seem far removed from the radical theatre and radio work he had been doing. And yet they are equally innovative and transgressive in their own way, something which Magee seems to have instinctively understood. He would from now on be a stalwart character actor in the burgeoning horror and exploitation genres. When Masque, shot by a young Nic Roeg, was released, reviewers noted Corman's many playful nods to late modernist auteurs like Bergman. But Magee's strange evacuated style is just as important, an even more subtle intertext blurring the boundaries between high and low culture.

Magee's detective in Richard Attenborough's fine psychological thriller Séance on a Wet Afternoon (1964) is another case in point. This is one of the first films that really takes advantage of Magee's extraordinarily subtle facial expressiveness. In one memorable scene Attenborough uses a close-up shot of Magee from below as part of a reverse-angle sequence in which his detective questions the suburban medium he suspects of kidnap. Magee's voice is at once affectless and insinuating, an even, terrible murmur. The words are gentle, understated, designed to put the suspect at her ease. But Magee's face, filling the 
screen as it looks down at us is mask-like, his gaze inscrutable. As viewers we occupy momentarily the subject-position of the guilty medium, who so desperately wants to ascertain whether she is a suspect or not, but cannot tell because of the enigma of the detective's face. It is a very disorientating and profoundly historical moment, when the functional, generic nature of character acting and the inhuman absorption of the Beckettian come together and slowly turn around one another.

Contrast the positive reviews of such 60 s work in television and film to that of the response to his work on radio, which now often describes his appearances with a weary sense of déjà $v u$. After playing Vladimir opposite Wilfred Bramble's Estragon in MacWhinnie's well-received radio Godot of $27^{\text {th }}$ April 1960, Magee appears in new Beckett work three more times before 1965, as well as in many repeats of All that Fall and the monologues. The new work consists of The Old Tune on $23^{\text {rd }}$ August 1960, Words and Music on $13^{\text {th }}$ Nov. 1962 and finally Cascando on $6^{\text {th }}$ October 1964. Even such a friend and ardent supporter as Barbara Bray senses something is amiss. In a discussion of The Old Tune on the Home Service, while defending the script, she argues that there were deficiencies in the performances (Bray had actually produced the programme) ${ }^{35}$ A review of Words and Music goes further, saying that Magee is 'extravagant' and, in a highly symptomatic phrase, 'always the same'.

Beckett himself seems to have been conscious of the close identification of his radio drama with Magee's vocal style. Alert as ever to the relationship between the work and the medium of its transmission, Beckett acknowledges it by naming one character in Words and Music 'Croak'. Coming after a succession of critics have used this exact word to describe Magee's performances suggests a degree of wry recognition of the standardizing effects of such characterisation, and an attempt to exploit it. It's a risky manoeuvre though, and as recorded above, some

\footnotetext{
${ }^{35}$ BBC Written Archives, 'The Critics', 12th March, 1961.
} 
reviews of the play were scathing, confirming the suspicion that Beckett's work was suffering from the excesses of Magee's Beckettian character-acting.

What we have here is a dilemma that powerfully condenses the opportunities and pitfalls of high-cultural production in late modernity. The attempt to reach a mass audience through the technologies of radio, TV and film entails a potentially debilitating exposure to the techniques and tactics of popular culture. Magee's restless movement between the Third Programme, the fringe and mainstream stage, film and television, and his corresponding oscillation between Beckett and mass culture, produces a fertile and symptomatic mode of performance. It is one that imports mass media standardization of character into high culture, and avantgarde ambiguity and resistance to interpretation into the popular. When this works, as in Krapp and Seance, it is electric. But the reifying, standardizing effects of the generic are immense, and this was Magee's fate at points in his 1960s radio and theatre work, whether in Beckett, or where he applied his Beckettian style to the work of others. Slighting references to the voice in particular, and its distorting effects on reception, become common: for one reviewer it is 'a caressing drone I am unable to disentangle from all the parts in Beckett'. ${ }^{36}$ For another, more troublingly: 'Patrick Magee's voice ... making a meal of every phrase, has become as much of a mannerism as the content of the plays'. ${ }^{37}$ A later comment suggests that Magee 'cannot help investing every syllable he articulates with at least twice as many meanings as the letters indicate' ${ }^{38}$ On such occasions the generic Beckettian mannerisms are reduced to mere signs of profundity, in the same way that a set jaw and a glower are shorthand for the B-movie toughs with which Magee was paying the bills.

I want to conclude by considering three accounts of the major roles that Magee created for the RSC in 1964: Harold Pinter's The Birthday Party, Beckett's

\footnotetext{
${ }^{36}$ Gilliat, P., The Observer, July $18^{\text {th }} 1965$.

${ }^{37}$ Ferris, P., The Observer, Nov. 18, 1962.

${ }^{38}$ The Stage July 19th, 1973.
} 
Endgame (in effect a transfer from the Paris performance mentioned above), Peter Weiss's Marat/Sade and David Rudkin's Afore Night Comes. Magee played the lead in all four plays, stamping his own authority on each individual production to such an extent that Pinter, in the aforementioned letter to his friend called it 'your season' rather than the RSC's. ${ }^{39}$ In some ways this is the pinnacle of Magee's career: immediately afterwards he will win a Tony on Broadway for Marat/Sade, and become for a time a fixture in the West End.

Once again The Times homes in on the Beckettian 'croak' in Afore Night Comes: 'Patrick Magee plays the Irish victim with a gross display of vocal mannerisms. It would be interesting to see whether Mr Rudkin writes 'wha...' as often as $\mathrm{Mr}$ Magee croaks it'. ${ }^{40}$ Similarly in The Sunday Times J. G. Lambert, after admiring Magee's 'restraint' in The Birthday Party, emphasizes the overwhelming physicality of Magee's voice in Rudkin's play: 'a shower of vocal eccentricities, of yelps and whinnies and saw-edged cachinnations'. ${ }^{41}$ The same reviewer notes a significant softening of the tone in Endgame, however, saying that in the RSC production both Magee and McGowran 'presumably with the author's permission - generate a good deal more human warmth than we were allowed in either the French or the English productions of 1957-8'. ${ }^{42}$ In a long, insightful Sunday Times Supplement article describing the rehearsals for the Paris Endgame, Clancy Signal, corroborating Lambert's review, notes the way Beckett wanted both actors to play their parts realistically, in an 'ordinary', naturalistic way: 'more interest, more interest' he says, which seems to indicate that the actors had been

\footnotetext{
${ }^{39}$ Harold Pinter Archive, British Library Manuscript Collections, Special Personal Correspondence: Add MS $88880 / 71$

${ }^{40}$ The Times, June 26, 1964.

${ }^{41}$ Sunday Times, June $28^{\text {th }} 1964$.

${ }^{42}$ Ibid.
} 
employing the 'toneless' monotonous voice that Beckett had demanded in previous stagings, and which Magee had made his own. ${ }^{43}$

The reception of, and commentary on, the 1964 RSC season thus records the presence of all the major strands of Magee's acting style as it had developed over the previous seven years. The extravagant ostensive croak of Afore Night Comes channels the Beckettian voice that has its roots in the Irish Players and the solo radio work, though heightened and standardized under the influence of generic character acting. The enigmatic monotonous mechanized voice initially present in the Endgame rehearsals is an iteration of the enigmatic heavies of the TV and film work, though it too has its origins in the avant-garde automatism of the radio work with MacWhinnie and Beckett. The 'restraint' of the eventual performance in Endgame harks back to Krapp, and marks a similar example of the successful integration of the other strands. For there is no relapse into simple naturalism in Magee's RSC performances. So much will become clear from the responses of Harold Pinter and Peter Brook.

Here is Pinter, in a letter to Magee, describing Marat/Sade at the Aldwych:

I can't remember seeing such innerness, such pain, expressed so economically, so terribly, so richly. (Hamm the only other character that springs to mind - played by an actor called Magee, I believe). De Sade was excruciatingly moving - truly so - the delicacy! And the desperation. I shall never forget your posture, your eyes, head, your appraisal of your creation. Wonderful. With McCann, Hamm and Sade your season is a triumph. ${ }^{44}$

\footnotetext{
${ }^{43}$ Clancy Sigal, 'Is This the Person to Murder Me?', Sunday Times Colour Magazine, 1st March 1964, pp. 64 69.

${ }^{44}$ Harold Pinter Archive, British Library Manuscript Collections, Special Personal Correspondence: Add MS $88880 / 7 /$
} 
Pinter's notion of 'your appraisal of your creation' is slightly ambiguous, in that it may refer to Sade's judgement on the play-within-a-play that he is directing at Charenton. More likely, however, given the references to economy and delicacy, it is Magee's own distance from the character he is inventing that is being referred to, the subtle, fleeting trace of self-consciousness, the slight trace of the 'apparatus', that marks performance out as performance. Pinter implicitly ascribes this distance to theatrical self-consciousness, but I want to suggest that this self-consciousness is also a trace of Magee's transmedial experimentation. Whereas in the Rudkin play Magee's generic vocal mannerisms collapse into the kind of caricature he was increasingly prone to, for Sade Magee builds the blank, generic distance of the character actor into the delicate displacement that Schaffer admires in Richardson. This allows his character, as Sade does in the texts Magee studied, to seem to dispassionately observe his own insanity.

Peter Brook is similarly taken by Magee's performance in The Birthday Party. He begins by criticizing Genet's search for 'lyricism' as a betrayal of the everyday, and dismisses 'grotesque masks, heightened make-up, hieratic costumes, declamation and balletic movement are somehow ritualistic ... and consequently lyrical'. This sounds like a description of Yeats' drama, and it is worth remembering what Magee himself later said of Brook's direction: 'I think Peter Brook's a marvellous psychologist in his own right. It's very difficult to explain what he does, but he's good at stopping you. One day during the Marat Sade he said to me - very discreetly and politely - it's not Yeats you know' ${ }^{45}$

As an alternative to Genet's or Yeats' (and Magee's, it seems) ostentation, Brook's notion of ritual is discovered in simple, everyday action:

Every action happens in its own right and everything action is an analogy of something else. I crumple a piece of paper: this gesture is complete in

\footnotetext{
${ }^{45}$ Hayman, R., 'Beckett's choice: Patrick Magee’ The Times, 2 Dec. 1975: p.10.
} 
itself: I can stand on a stage and what I do need be no more than what appears at the moment of the happening. It is also a metaphor. Anyone saw Patrick Magee slowly tearing strips of newspaper precisely as in life and yet utterly ritualistically in Pinter's The Birthday Party will know what this means. ${ }^{46}$

For Brook the minimal difference that inscribes itself in a truthful performance is found in the doubleness of an everyday, yet immersive action, its status as at once autonomous gesture 'complete in itself' and exfoliating surplus as an 'analogy for everything else'. This coincidence of the distant and the immersed is similar to the one Pinter sees in Sade. The difference is that where Pinter implies that it is the trace of actorly self-consciousness that prevents the absolute closure of inwardness, and so opens the performance to the audience and the world, for Brook it is the performer's feeling for minimalist ritual structures that does it. As with Pinter however, I suggest that Magee's struggle with the norms of the expanded field of character acting also has a bearing on this.

We can now turn finally to Schaffer's rather conflicted account of the 1967 film of Marat/Sade in 'Notes on Film Acting'. There is a structural homology with the other accounts, despite the shift from stage to screen:

De Sade was the still eye of the hurricane, in Magee's hands a model of cold composure comparable to the brilliant ice sculpture of Richardson's Dr. Sloper in The Heiress. With de Sade Magee's considerable qualities of voice, carriage and sheer presence were enough to bring him magnificently through. Further, de Sade clearly had some real meaning for Magee, and the sympathetic vibration showed in the resonance of his acting. ${ }^{47}$

\footnotetext{
${ }^{46}$ Brook, P., The Empty Space: A Book About the Theatre: Deadly, Holy, Rough, Immediate (New York: Touchstone, 1998), p. 119.

${ }^{47}$ Schaffer, p. 106.
} 
As pointed out earlier, for Schaffer the most skilled character acting in film is that which allows an actor to both remain distantly 'themselves' but, using a finelytuned acting 'apparatus', inhabit a convincingly inward character. Ralph Richardson is such an actor, according to Schaffer, and here he compares Magee to the Englishman. This contrasts with 'personality' acting, in which younger actors such as Gene Hackman and Malcolm McDowell 'become someone else' completely through intense personal identification. There is the illusion of immediate access to presence, without any reminder of artifice. This is because the actor can 'concentrate almost exclusively on expressive behaviour because the role strikes such a responsive chord in the actor's psyche that he doesn't have to worry about distinctive traits and mannerisms'.

The odd thing about the description above is that with his reference to Magee's 'sympathetic vibration' with Sade, Schaffer seems to assimilate Magee to this second model too. Magee thus falls between the best screen character acting (which seems to me very close to what Pinter is describing in his response to the Marat/Sade) and personality acting, which is based on rare occasions when an actor finds a role that has 'real meaning' due to the proximity of the role to his or her own psychology. The way that Magee's performance causes Schaffer's opposition between the poles of personality and character to collapse is deeply symptomatic. For it points to the continuing presence in the essay of another important but now disavowed factor, ie character acting in the less exalted, popcultural sense. By asserting that there must be a secret psychic affinity between Magee and Sade, Schaffer is clearly drawing, consciously or unconsciously, on Magee's by now cult image as a consummate player of brutes and villains. Similarly, when Sigal is considering Magee's Sigal draws attention to Magee's status as a character actor playing specific roles for the screen, describing him as 'dark-eyed, handsome, often cast on TV and in movies as a belligerent villain'. ${ }^{48}$

\footnotetext{
${ }^{48}$ Ibid., p. 64.
} 
All three of these descriptions of Magee's acting, by a great playwright, a great director and a very subtle critic, find a moment of non-identity in Magee's performance as Sade and McCann. Pinter and Brook dra on conventionally dualist ideas about form and content, structure and feeling, to burrow into the nature of Magee's achievement, and their descriptions are elegant, apposite and enlightening. But it is the way that Magee's style unravels Schaffer's neat typologies that is most significant, and adds a crucial element to the others. Schaffer's essay, looking back on Magee's career from 1971, at a moment when the actor has achieved his greatest prominence, inscribes in its own contradictions the complex hinterland of Magee's style and its reception. The fact that Schaffer effectively describes Magee's Sade in terms of a combination of all three of his main modes of character acting demonstrates the hybrid nature of the actor's performance style, and his position at the confluence of the aesthetic, historical but not least the commercial dynamics of the Sixties.

Pinter wrote to Magee again in the mid-1960s, a propos of the latter's relations with his agent, saying 'You ain't properly estimated your own value and desirability, mate'. ${ }^{49}$ It's a typically astute comment from someone who knew the actor and his professional life well, and behind it lies a kind of frustration at Magee's seeming inability or disinclination to discriminate between the roles he choose and played, or to fully appreciate and manage his own cultural capital. In 1975, meanwhile, in the course of a protracted debate about the setting of Magee's standard fee, Martin Esslin wrote an internal, confidential BBC memo in his role as radio producer. It gives a highly informed insider's view of Magee's unique position within the post-War British entertainment industry: 'His case is peculiar in some ways. He was originally a character actor and is

\footnotetext{
${ }^{49}$ Harold Pinter Archive, British Library Manuscript Collections, Special Personal Correspondence: Add MS $88880 / 7 /$
} 
superb in very small parts. On the other hand, he has become a star in films and on the stage'. ${ }^{50}$

Taken together these quotations from Pinter and Esslin condense the questions Magee's career and performance style pose for the adjudication of cultural value or status, and the categorization of modes of acting, in the multimedia moment of the 1960s and 1970s. His 'peculiar' position at crossroads of neo-avant-garde theatre, cult film, popular culture and the star system produces a continual displacement of performance style that serves to highlight the competing systems of representation his image functioned within. If, as Fredric Jameson says of 1970s cinema, the viewer's reading of film acting 'is not a direct passage from one character or actant another, but passes through the mediation or identification and decoding of the actor's status itself', then Magee's indeterminate status as theatre actor, cult figure, TV character actor and film star scrambles such decoding. ${ }^{51}$ Yet this is the key, for it is here, in an indeterminacy that interrogates the very idea of character and genre in the newly industrialized conditions of culture, that we find the source of Magee's considerable art.

\footnotetext{
${ }^{50}$ Letter from Martin Esslin to Brian Bachelor, DLE Manager, 2nd July, 1974, BBC Written Archives, RCONT1, Radio Contributors, Patrick Magee, Artists File 4 (1973-1982).

${ }^{51}$ Jameson F., Signatures of the Visible (London:Verso, 1992), p. 72.
} 